\title{
Effect of plant growth regulators on oil yield and biodiesel production of safflower (Carthamus tinctorius L.)
}

\section{Faizan Ullah and Asghari Bano*}

Department of Plant Sciences, Faculty of Biological Sciences, Quaid-i-Azam University, Islamabad, Pakistan.

* Correspondence author: banoasghari@gmail.com

Received: 02 August 2010; Accepted: 24 April 2011.

\section{ABSTRACT}

The aim of the present investigation was to determine the effect of plant growth regulators viz., kinetin, chlorocholine chloride (CCC) and salicylic acid (SA) on achene yield and oil quality of safflower (Carthamus tinctorius L.) Cv. Thori pertaining to biodiesel production. The growth regulators were applied at $10^{-5} \mathrm{M}$ as foliar spray during flowering (140 days after sowing). Kinetin was highly effective in increasing achene yield, 100 achene weight and oil refractive index. Maximum achene oil content was found in CCC treatment. Kinetin and CCC significantly decreased oil acid value, free fatty acid content (\% oleic acid) and specific gravity but increased oil pH. Kinetin was highly effective in increasing oleic acid (C18:1) but decreased the content of linoleic acid (C18:2). Oil extracted from achenes of CCC and Kinetin treated plants exhibited maximum (92\%) conversion into methyl esters.

Key words: Biodiesel, plant growth regulators, Safflower, oil quality

\section{INTRODUCTION}

Biodiesel defined as lower alkyl esters of long chain fatty acids is gaining interest throughout the world as a transportation fuel. The main advantages of using this alternative fuel to petroleum based diesel are its renewability, better quality of exhaust gas emissions, its biodegradability and also due to the fact that it does not increase the level of carbon dioxide in the atmosphere (Barnwal and Sharma, 2005).

The growth regulator salicylic acid enhances the plant growth, flower induction, nutrient uptake and photosynthesis (Hayat and Ahmed, 2007). Chlorocholine chloride is a growth retardant which enhances plant growth and development by improving sink source relationship (Singh et al., 1987). Kinetin, a synthetic cytokinin play important role in plant growth and development. It stimulates leaf expansion, development of reproductive organs and delays senescence (Mok, 1994).
Safflower (Carthamus tinctorius L.) belonging to family Asteraceae, is an annual, broadleaf oilseed crop. Presently, the major producers of safflower include the U.S.A, India, Mexico, Australia, Argentina, the Russian Federation, Canada, Ethiopia and Iran etc (Dajue, 1996). It is a neglected oil seed crop in Pakistan such that during 2004-2005, the total area under cultivation was only 48 hectares (Anon, 2005). It has been used as source of dye, folk medicine and food but it has not got any significant consideration as oil seed crop (Shah et al., 2005). The major problems associated with cultivation of this crop are its mechanical harvesting which is quite laborious accompanied by low yields. The absence of linolenic acid and presence of linoleic acid along with low color values, low unsaponifiables and lower content of free fatty acids render the utilization of safflower oil in paints and coatings etc (Smith, 1996). According to Rashid and Anwar (2008), safflower biodiesel can be successfully utilized in ignition compression engines. The present research work was aimed to improve the 
yield and oil quality of safflower through application of plant growth regulators pertaining to biodiesel production.

\section{MATERIALS AND METHODS}

Pot experiment was carried out in complete randomized design (CRD) in the ware house of Department of Plant Sciences, Quaid-i-Azam University, Islamabad. Seeds of safflower (Carthamus tinctourious L.) cv. Thori were obtained from National Agriculture Research Centre, Islamabad. The seeds were surface sterilized with $95 \%$ ethanol for 3 min and then with $10 \%$ chlorox solution for five min with shaking and thoroughly washed with sterile water. The seeds were sown in earthen pots measuring $27 \times 30 \mathrm{~cm}^{2}$ filled with clay, farm yard manure and sand in ratio of 3:2:1 and kept under natural environmental conditions during mid November, 2008 till maturity. The plant growth regulators were applied during flowering (140 DAS) as foliar spray by using common insecticide sprayer.

Treatments: C - Control; K-Kinetin (10-5M); SA - Salicylic acid $\left(10^{-5} \mathrm{M}\right)$ and $\mathrm{CCC}-$ Chlorocholine chloride $\left(10^{-5} \mathrm{M}\right)$.

Seed oil content was estimated by NMR (Nuclear magnetic resonance) test (Robertson and Morrison, 1979). The oil was extracted with petroleum ether in a Soxhlet apparatus (AOAC, 1960). Oil acid value, free fatty acid content (as oleic acid) and refractive index was determined according to AOAC (1990). Specific gravity was determined using density bottle according to Pearson (1980). For determination of oil pH, $2 \mathrm{gm}$ of the oil sample was poured into a clean dry
$25 \mathrm{ml}$ beaker and $25 \mathrm{ml}$ of hot distilled water was added to the sample in the beaker and stirred slowly. It was than cooled in a water bath to $25^{\circ} \mathrm{C}$. The pH electrode was standardized with buffer solution, immersed into the sample and the $\mathrm{pH}$ value was recorded (Akubugwo and Ugbogu, 2007). The fatty acids methyl esters $(0.5 \mu \mathrm{l})$ were analyzed in a gas chromatograph (Shimadzu QP 5050) equipped with a flame ionizing detector (FID) and a fused silica capillary column (MN FFAP (50 m x $0.32 \mathrm{~mm}$ i.d; film thickness $0.25 \mu \mathrm{m}$ ). Helium was utilized as carrier gas. The column temperature was maintained at $110^{\circ} \mathrm{C}$ for $0.5 \mathrm{~min}$, raised to $200^{\circ} \mathrm{C}$ at $10^{\circ} \mathrm{C} / \mathrm{min}$ tills $10 \mathrm{~min}$. Biodiesel was produced through base catalyzed transesterification reaction as described by Nosheen et al. (2010). The ratio of methanol to oil was $9: 1$ at $1 \% \mathrm{NaOH}$ concentration. The yield of biodiesel was determined on \% w/w conversion of safflower oil to biodiesel (Rashid and Anwar, 2008).

The data was analyzed statistically by Analysis of Variance technique (Steel and Torrie, 1980) and comparison among treatment means was made by Duncan's Multiple Range Test (DMRT) (Duncan's, 1955).

\section{RESULTS AND DISCUSSION}

Results presented in Table.1 revealed that kinetin treatment significantly increased number of achenes plant ${ }^{-1}$ and number of achenes capitulum ${ }^{-1}$ at $P<0.05$. All the growth regulators significantly increased the 100 achene weight as compared to control, maximum increase being observed in kinetin treatment. Chlorocholine chloride effectively increased the seed oil content by $4 \%$ over control (Table 1).

Table 1. Effect of plant growth regulators on number of achenes plant ${ }^{-1}$, Number of achenes capitulum ${ }^{-1}, 100$ achene weight $(\mathrm{g})$ and achene oil content (\%) of safflower. The growth regulators were applied as foliar spray during flowering (140 DAS). The data represents mean of three replicas.

\begin{tabular}{lcccc}
\hline \multicolumn{1}{c}{ Treatments } & $\begin{array}{c}\text { Number of } \\
\text { achenes plant }^{-1}\end{array}$ & $\begin{array}{c}\text { Number of } \\
\text { achenes capitulum }\end{array}$ & $\begin{array}{c}\text { 100 achene } \\
\text { weight (g) }\end{array}$ & $\begin{array}{c}\text { Achene oil } \\
\text { content (\%) }\end{array}$ \\
\hline Control & $36.07 \mathrm{~b}$ & $11.96 \mathrm{bc}$ & $5.97 \mathrm{~b}$ & $29.22 \mathrm{~b}$ \\
Kinetin & $42.56 \mathrm{a}$ & $18.89 \mathrm{c}$ & $7.040 \mathrm{a}$ & $29.93 \mathrm{ab}$ \\
Salicylic acid & $29.02 \mathrm{c}$ & $9.66 \mathrm{c}$ & $6.38 \mathrm{ab}$ & $27.59 \mathrm{c}$ \\
Chlorocholine chloride & $36.35 \mathrm{~b}$ & $14.00 \mathrm{~b}$ & $6.85 \mathrm{a}$ & $30.58 \mathrm{a}$ \\
\hline
\end{tabular}

Kinetin improves the export of assimilates from source organs and regulate source-sink relations (Roitsch and Ehness, 2000). Similar increase in seed yield by kinetin application was reported by Fatima and Bano (1998) in soybean and Faizanullah et al. (2010) in linseed. Similarly, Pan and Xu (2010) found that foliar application of benzyl adenine, a synthetic cytokinin markedly increased seed yield of biodiesel plant Jatropha curcas L. The observed increase in yield my be 
attributed to the enhanced translocation of assimilates from leaves to reproductive parts. The CCC application increased the achene weight and oil content. The increased seed oil content by CCC application has been reported by Faizanullah et al. (2010) in linseed. Growth retardants have been reported for maintaining internal hormonal balance and efficient sink source relationships (Singh et al., 1987). These efficient sink source relationships by CCC may be responsible for increasing the seed oil content in Safflower.

CCC and kinetin significantly decreased oil acid value and specific gravity. Maximum decrease in free fatty acid content (as oleic acid) was recorded in CCC treatment with concomitant increase in oil pH (Table 2).

Table 2. Effect of plant growth regulators on oil specific gravity $\left(\mathrm{g} / \mathrm{cm}^{3}\right)$, acid value $(\mathrm{mg} \mathrm{KOH} / \mathrm{g})$, free fatty acids (as oleic acid) and pH. The growth regulators were applied as foliar spray during flowering (140 DAS). The data represents mean of three replica.

\begin{tabular}{lcccc}
\hline \multicolumn{1}{c}{ Treatments } & Specific gravity & Acid vale & Free fatty acid content & Oil pH \\
\hline Control & $0.92 \mathrm{a}$ & $4.9 \mathrm{a}$ & $1.9 \mathrm{a}$ & $5.2 \mathrm{~b}$ \\
Kinetin & $0.91 \mathrm{~b}$ & $3.5 \mathrm{~b}$ & $1.6 \mathrm{a}$ & $5.5 \mathrm{ab}$ \\
Salicylic acid & $0.92 \mathrm{a}$ & $3.8 \mathrm{ab}$ & $1.8 \mathrm{a}$ & $5 \mathrm{~b}$ \\
Chlorocholine chloride & $0.90 \mathrm{c}$ & $2.6 \mathrm{c}$ & $1.2 \mathrm{~b}$ & $5.7 \mathrm{a}$ \\
\hline
\end{tabular}

Specific gravity is among the most important properties of biodiesel because some important performance indicators (cetane number and heating values) are associated with it (Tat and Van Gerpen, 2000). These findings are in agreement with previous findings of Faizanullah et al. (2010) who found that kinetin and CCC significantly decreased oil acid value of linseed. Similarly, Sawan et al. (1993) found marked decrease in oil acid value of cotton seed in response to foliar application of CCC. The acidity of vegetable oil is correlated with the content of free fatty acids (Kusdiana and Saka, 2003). The CCC and kinetin treatments significantly increased oil pH which was negatively correlated with the content of free fatty acids. In base catalyzed method of biodiesel production, the amount of catalyst used depends on the acidity of the crude vegetable oil. The presence of free fatty acids in vegetable oil cause deactivation of the basic catalysts which results in the addition of an excessive amount of alkali, leading to the formation of gels that cause problems in the separation of glycerol and yield losses of biodiesel (Crabble et al., 2001). Therefore, it can be inferred that achene oil extracted from safflower plants treated with kinetin and CCC at flowering stage can lead to the production of good quality biodiesel.

Kinetin was highly effective in increasing oil refractive index whereas; all other treatments were ineffective. Similarly, kinetin significantly increased oil oleic acid (C18:1) content with concomitant decrease in linoleic acid (C18:2). Furthermore, significantly higher ester production (92.4 and 92\%) were obtained for CCC and kinetin treatments respectively (Table 3).

Table 3. Effect of plant growth regulators on oil refractive index (nd $40{ }^{\circ} \mathrm{C}$ ), oleic acid (\%), linoleic acid (\%) and biodiesel yield (\%), The growth regulators were applied as foliar spray during flowering (140 DAS). The data represents mean of three replicas

\begin{tabular}{lcccc}
\hline \multicolumn{1}{c}{ Treatments } & Refractive index & Oleic acid (C18:1) & Linoleic acid (C18:2) & Biodiesel yield \\
\hline Control & $1.47 \mathrm{~b}$ & $14.6 \mathrm{~b}$ & $72 \mathrm{a}$ & $89 \mathrm{~b}$ \\
Kinetin & $1.5 \mathrm{a}$ & $18 \mathrm{a}$ & $69 \mathrm{~b}$ & $92 \mathrm{a}$ \\
Salicylic acid & $1.47 \mathrm{~b}$ & $15 \mathrm{~b}$ & $73 \mathrm{a}$ & $89.7 \mathrm{~b}$ \\
Chlorocholine chloride & $1.47 \mathrm{~b}$ & $15 \mathrm{~b}$ & $72 \mathrm{a}$ & $92.4 \mathrm{a}$ \\
\hline
\end{tabular}

Kinetin has been reported to improve the oleic acid content at the cost of linoleic and linolenic (C18:3) acid in cotton (El-Dayem and El-Deeb, 2000). The fatty acid composition of vegetable oil notably affects the quality and 
quantity of biodiesel. The high unsaturation of vegetable oil leads to the production of biodiesel with low cetane numbers which is an important indicator of biodiesel quality (Ramos et al., 2009). Previous studies showed that low cetane number of biodiesel was associated with more highly unsaturated components such as the esters of linoleic acid (C18:2) (Knothe et al., 2003) and therefore, the presence of monounsaturated fatty acids (C18:1) gave a higher cetane value to biodiesel of olive oil (Ramos et al., 2009). McCormick et al. (2007) have reported decrease in oxidation stability of biodiesel with increase in polyunsaturated methyl esters. In the transesterification process of biodiesel production, a triglyceride reacts with a short chain alcohol in the presence of a catalyst, producing a mixture of fatty acid alkyl esters and glycerol (Schuchardt et al., 1998). The observed increase in yield of biodiesel by CCC and kinetin might be attributed to the experiential decrease in oil acid value and free fatty acid contents since free fatty acids does not convert into methyl esters during transesterification (Freedman et al., 1984).

\section{CONCLUSION}

It can be inferred that application of plant growth regulators viz. kinetin and CCC as foliar spray $\left(10^{-5} \mathrm{M}\right)$ during flowering in safflower can improve oil yield and quality which can be utilized in a sustainable manner in commercial scale production of good quality biodiesel. Moreover, the kinetin treatment enhances the conversion of oil to methyl esters in a base catalyzed transesterification reaction.

Acknowledgement: The authors acknowledge the help rendered by the Higher Education Commission for financial support during this research work under R\&D research grant entitled 'Physiological and Biochemical measures to improve quantity and quality of Biodiesel'.

\section{REFERENCES}

Akubugwo IE, Ugbogu AE (2007) Physiochemical studies on oils from five selected Nigerian plant seeds. Pak. J. Nutri. 6: 75-78

Annonymous (2006) Agriculture statistics of Pakistan. Ministry of Food, Agriculture and Livestock. Food Agric Government of Pakistan. Livestock Div. Economic Wing, Islamabad.

AOAC (1990) Official methods of analysis. 15th ed. Association of Official Analytical Chemists, Arlington, VA.
Association of Official Agricultural Chemistry (1960) Official Methods of Analysis. Association of Official Agricultural Chemistry, Washington, DC.

Barnwal BK, Sharma MP (2005) Renewable and Sustainable Energy Reviews. 9: 363-378.

Crabble E, Nolasco-Hipito C, Kobayashi G, Sonomoto K, Shizaki A. (2001) Biodiesel production from crude palm oil and evaluation of butanol extraction and fuel properties. Process Biochem. 37: 65-71.

Dajue Li, H Mündel. 1996. Safflower. Carthamus tinctorius L. Promoting the conservation and use of underutilized and neglected crops. 7. Institute of Plant Genetics and Crop Plant Research, Gatersleben/International Plant Genetic Resources Institute, Rome, Italy.

Duncan DB (1955) Multiple range and Multiple F Tests. Biometrics. 11: 1-42. El-Dayem H M M A, El-Deeb A E A (2000) Effect of some plant growth regulators on growth, yield components and some chemical constituents of cotton plant. Ann. Agric. Sci. Moshtohor. 38: 907-925

Faizanullah, Bano A, Nosheen A (2010) Role of plant growth regulators on oil yield and biodiesel production of linseed (Linum usititimum $\mathrm{L}$ ). J. Chem. Soc. Pak. 32:668-671

Freedman B, Prydeand EH, Mounts TL (1984) Variables affecting the yields of fatty esters from transesterified vegetable oils. J. Am. Oil Chem. Soc.61: 1638-1643.

Fatima Z, Bano, A (1998) Effect of seed treatment with growth hormones and Rhizobium on the oil contents, nitrogen fixation and yield of soybean. Pak. J. Bot. 30: 83-86.

Hayat S, Ahmad A (2007) Salicylic Acid: A Plant Hormone. Springer, Dordrecht, The Netherlands.

Knothe G, Matheaus AC, Ryan TW III (2003) Cetane numbers of branched and straight-chain fatty esters determined in an ignition quality tester. Fuel 82: $971-975$

Kusdiana D, Saka S (2003) Methyl esterification of free fatty acids of rapeseed oil as treated in supercritical methanol. J Chem Eng Jpn. 34: 373.

McCormick RL, Ratcliff M, Moens L, Lawrence R (2007) Several factors affecting the stability of biodiesel in standard accelerated tests. Fuel Process Technol. 88:651-657

Mok DWS, Mok MC (1994) "Cytokinins: chemistry, activity and function." C $\mathrm{RC}$ press Inc., Boca Raton.

Mullin P (1994) New research focuses on identifying fuel properties that influence emissions. Diesel Progress Engine and Drives. 94.

Nosheen A, Bano A, Faizanullah (2010) Optimization of biodiesel production from yellow sarson (Brassica campestris L.) oil. Energy Sources Part A. In Press.

Pan B, Xu Z (2010) Benzyladenine Treatment Significantly Increases the Seed Yield of the Biofuel Plant Jatropha curcas. J Plant Growth Regul: DOI 10.1007/ s00344- 010-9179-3

Pearson D (1976) The Chemical Analysis of Food. Churchill, Livingstone. 488-496.

Ramos MJ, Fernandez C.M, Casas A, Rodriguez L, Perez A (2009) Influence of fatty acid composition of raw materials on biodiesel properties. Bioresour. Technol. 100: 261-268.

Rashid U, Anwar F (2008) Production of Biodiesel through Base-Catalyzed Transesterification of Safflower Oil Using an Optimized Protocol. Energy Fuels. 22: $1306-1312$

Robertson JA, Morrison WH (1979) Analysis of oil content of sunflower seed by NMR. J. Am Oil Chem. Soc. 56: 961-964.

Roitsch T, Ehness R (2000). Regulation of source/sink relations by cytokinins. Plant Growth Regul. 32: 359-367.

Schuchardt U, Sercheli R, Vargas RM (1998) Transesterification of vegetable oils: a review. J Braz Chem Soc. 9 (1): 199-210. 
Shah NA, Shah H, Akmal N (2005) Sunflower area and production variability in Pakistan: opportunities and constraints. HELIA 28 (43):165-178

Singh VP, Singh M, Bhardwaj SN (1987) Foliage characters in relation to biomass and seed cotton productivity in Upland cottons (Gossypium hirsutum L.). Annals Agric. Res. 8:130-134.

Steel RG, Torrie GH (1980) Principles and Procedures of Statistics: A Biometrics Approach MC. Grow Hillbook co. New York.
Sawan ZM, Basyony A E., McCuistion W L, El Farra A H A (1993) Effect of plant population densities and application of growth retardants on cottonseed yield and quality. J. Am. Oil. Chem. Soc 70 (3): 313-317

Smith J R (1996) Safflower. AOCS Press, Champaign, II, P.624

Tat ME, Van Gerpen JH (2000) The specific gravity of Biodiesel and its blends with diesel fuel. J. Am. Oil. Chem. Soc. 77 (2): 115-119. 